\title{
Protecting our most vulnerable elders from abuse
}

\author{
Barbara Sibbald BJ, Jayna M. Holroyd-Leduc MD
}

I n March 2012, Canada's Parliament gave first reading to Bill C-36, Protecting Canada's Seniors Act, which recognizes that the major impact of crimes perpetuated on the elderly should be taken into account during sentencing. If passed, this legislation will address the most egregious incidents of elder abuse, but it will not solve the broader issues. Abuse is chronically under-reported, but we know that in $2009,35 \%$ (or 2765) of the 7900 reported violent crimes against seniors were committed by family members. ${ }^{1}$ Locking up those family members does not address the underlying causes. Nor does it address most incidents. An estimated 4\%-10\% of Canadian seniors experience some form of neglect or abuse. ${ }^{2}$ That means that, of the 5 million Canadians aged 65 years and older, $200000-500000$ will be victims of abuse. What about these seniors? And what about the people who care for them?

Caregivers who abuse elders aren't necessarily bad people; some are people caught in bad situations. The persistent lack of resources to support Canada's estimated 2.7 million $^{3}$ caregivers is no doubt a factor in many cases of abuse. Only $11 \%$ (or fewer) of caregivers now receive formal support. ${ }^{3}$ No wonder $18 \%$ of female and $8 \%$ of male caregivers say their health is affected by looking after an elder. ${ }^{3}$ Although some caregivers are undoubtedly opportunistic or sociopathic, many may be simply overwhelmed. Efforts to detect abuse must continue; a study of the national prevalence of abuse in the community, to be undertaken by the National Initiative for the Care of the Elderly, is a positive step. However, a case can also be made for preventive measures that decrease the burden on caregivers.

Elder abuse includes physical abuse, physical neglect, psychological abuse, financial mistreatment, personal rights violation and sexual abuse. Elders most at risk of abuse are those who have poor health or disability and who are divorced or separated. ${ }^{4}$ Those most likely to commit elder abuse have substance abuse issues, lower education levels than the victim, and/or financial dependence on the victim. ${ }^{4}$ Physical and social isolation, and ageism, sexism and linguistic or minority dynamics also play a role. ${ }^{4}$

Although there are many things that could be done to help those who care for the elderly at home, the following 3 measures are a promising place to start.

The first is direct financial support so that caregivers have some income security. ${ }^{3}$ Their ability to work outside the home is severely curtailed by their responsibilities in the home, and they are saving taxpayers money and improving elders' quality of life by allowing them to stay in their home. So why not ease the way for caregivers with some financial compensation? These federal measures could be indirect, such as tax

breaks, or direct, such as employment insurance. Australia and Germany currently offer programs to financially support caregivers. This money will reduce caregivers' dependency on the elders' pension and gives caregivers the freedom to purchase respite care. One potential source of support in Canada is the federal guaranteed income supplement, which qualifying elders may not get because they don't know to apply for it. This supplement should be automatically provided to those who qualify based on income tax returns.

The second solution is to increase services for both caregivers and those being cared for. Services, which now vary substantially across Canada, should include formal education, training and respite. Provincial home care support could also be expanded to include more services.

The third solution could be to establish support and resource groups for caregivers in all provinces and territories. These groups would serve as clearing houses of available resources, such as respite care, as well as access to peer and professional support. Access to these groups could be online or through physicians and other health professionals. Caregivers are essential members of the home care team and should be provided with the necessary support.

If we don't act, the problem is going to get worse. One model estimates that the demand for official caregivers will nearly double to 1.4 million within 3 decades. ${ }^{3}$ The Protecting Canada's Seniors Act only touches the most egregious aspect of the problem. The broader solution lies in a more comprehensive approach that requires the support of government and the Canadian health care system.

Our elders have supported us throughout their lives; it is time we return the favour.

\section{References}

1. Backgrounder: elder abuse legislation. Ottawa (ON): Department of Justice; 2012 Available: www.justice.gc.ca/eng/news-nouv/nr-cp/2012/doc_32716.html (accessed 2012 July 24).

2. Bain P, Spencer C. Fact sheet 2: What is abuse of older adults? Ottawa (ON): Federal/Provincial/Territorial Ministers Responsible for Seniors in Canada; 2009.

3. Keefe J. IRRP Study. Supporting caregivers and caregiving in an aging Canada. Montréal (QC): Institute for Research on Public Policy; 2011. Available: www.irpp .org/pubs/IRPPstudy/IRPP_Study_no23.pdf (accessed 2012 July 23).

4. Poole C, Rietschlin J. Intimate partner victimization among adults aged 60 and older: an analysis of the 1999 and 2004 General Social Survey. J Elder Abuse Negl 2012;24:120-37.

Competing interests: See www.cmaj.ca/site/misc/cmaj_staff.xhtml

Affiliations: Barbara Sibbald is deputy editor, Analysis and Humanities, CMAJ; and Jayna M. Holroyd-Leduc is associate professor, Geriatric Medicine Section, Departments of Medicine and Community Health Sciences, University of Calgary, Calgary, Alta., and associate editor, Reviews, CMAJ.

Correspondence to: CMAJ editor,pubs@cmaj.ca

CMAJ 2012. DOI:10.1503/cmaj.121472 